\title{
CHEROKEE ARCHAEOLOGICAL LANDSCAPES AS COMMUNITY ACTION
}

\author{
Paisagens arqueológicas Cherokee como ação \\ comunitária \\ Kathryn Sampeck* \\ Johi D. Griffin Jr. **
}

\begin{abstract}
An ongoing, partnered program of research and education by the authors and other members of the Tribal Historic Preservation Office of the Eastern Band of Cherokee Indians contributes to economic development, education, and the creation of identities and communities. Landscape archaeology reveals how Cherokees navigated the pivotal and tumultuous 16th through early 18th centuries, a past muted or silenced in current education programs and history books. From a Cherokee perspective, our starting points are the principles of gadugi, which translates as "town" or "community," and tohi, which translates as "balance." Gadugi and tohi together are cornerstones of Cherokee identity. These seemingly abstract principles are archaeologically detectible: gadugi is well addressed by understanding the spatial relationships of the internal organization of the community; the network of relationships among towns and regional resources; artifact and ecofact traces of activities; and large-scale "non-site" features, such as roads and agricultural fields. We focus our research on a poorly understood but pivotal time in history: colonial encounters of the 16th through early 18th centuries. Archaeology plays a critical role in social justice and ethics in cultural landscape management by providing equitable access by
\end{abstract}

* Associate Professor, Illinois State University, Department of Sociology and Anthropology, Campus Box 4660, Normal, IL 61701. E-mail: ksampec@ilstu.edu

** Historic Sites Keeper, Tribal Historic Preservation Office, Eastern Band of Cherokee Indians. Qualla Boundary Reservation, P.O. Box 455, Cherokee, NC 28719, USA. 
First Nations to the potential benefits of cultural landscapes and meaningful participation in plans and actions regarding them.

Keywords: Collaborative archaeology, Landscape archaeology, Early Modern period, Southeastern United States, Research ethics

\section{RÉSUMÉ}

Un programme de recherche et d'éducation actuellement développé par les auteurs et d'autres membres du Tribal Historic Preservation Office de la Eastern Band of Cherokee Indians contribue directement au développement économique, à l'éducation ainsi qu'à la création d'identités et de communautés. L'archéologie du paysage révèle en effet comment les Cherokees ont traversé les années du tumultueux et fondamental seizième siècle jusqu'au début du dix-huitième, un passé tu ou ignoré dans les programmes actuels d'éducation ou les livres d'histoire. Du point de vue Cherokee, nos origines sont liées aux principes du gadugi, qui se traduit par 'ville' ou 'communauté,' et tohi, 'équilibre'. Gadugi et tohi constituent ensemble les pierres angulaires de l'identité Cherokee. Ces principes apparemment abstraits sont archéologiquement détectables : gadugi se comprend aisément via l'étude des relations spatiales de l'organisation interne de la communauté, le réseau de relations parmi les villes et les ressources régionales, les artefacts et écofacts inhérents aux activités, et les éléments à grande échelle « non sites » comme les routes et les champs agricoles. Notre recherche se concentre sur un temps historique peu étudié mais pourtant crucial : les rencontres coloniales du seizième siècle jusqu'au début du dix-huitième siècle. L'archéologie joue un rôle crucial dans la justice sociale et l'éthique de l'aménagement du paysage culturel en fournissant aux Premières Nations un accès équitable aux bénéfices potentiels des paysages culturels ainsi qu'à une participative significative au sujet des plans et actions les concernant.

Mots-clés: Archéologie collaborative; archéologie du paysage; période moderne; États-Unis du Sud-Est; éthiques de la recherche

\section{RESUMO}

Um programa de pesquisa e educação atualmente desenvolvido pelos próprios autores e outros membros do Tribal Historic Preservation Office of the Eastern Band of Cherokee Indians contribui diretamente para o desenvolvimento econômico, para a educação, e para a criação de identidades e comunidades. De fato, a arqueologia da paisagem revela como os Cherokees atravessaram o fundamental e tumultuado período entre o século dezesseis e o inicio do século dezoito, um passado silenciado nos programas de educação atuais e nos livros de história. Do ponto de vista Cherokee, as nossas origens são ligadas aos princípios de 
gadugi, traduzido por 'cidade' ou 'comunidade,' e tohi, 'equilibro.' Gadugi e tohi juntos são os pilares da identidade Cherokee. Estes princípios aparentemente abstratos são arqueologicamente perceptíveis: gadugi se entende claramente pelo estudo das relações espaciais da organização interna da comunidade, a rede de relações entre cidades e recursos regionais, artefatos e ecofatos ligados às atividades, e elementos de grande escala "não sítios", como os caminhos e os campos agrícolas. Nossa pesquisa está concentrada sobre um tempo histórico essencial ainda que pouco estudado: os encontros coloniais do século dezesseis até o inicio do século dezoito. A arqueologia tem um papel capital em termos de justiça social e ética da gestão da paisagem cultural, fornecendo às Primeiras Nações um acesso equipável aos benefícios potenciais de paisagens culturais assim como à uma participação significativa nos planos e ações a respeito deles.

Palavras-chave: arqueologia colaborativa; arqueologia da paisagem; época moderna; Sudeste dos Estados-Unidos; ética de pesquisa

\section{Introduction}

How is a community made? The social sciences, humanities, and biological sciences have devoted considerable efforts to understanding this deceptively simple question. The genesis and sustenance of communities invite us to consider both people and places, both the social and the geographic, and how their histories provide foundations for the future. ${ }^{1}$ One way to answer the question about how people create and sustain communities is from a Cherokee perspective, by evaluating evidence in terms of the principle of $S \mathrm{~L} \Gamma$ (gadahu), which can be translated as "town," that is, the physical place, architecture, and other elements of a settlement. Cherokees, one of the largest federally recognized Native American nations in the United States, have their origin in the southeastern United States and

1 This research was supported by funding from the Cherokee Preservation Foundation, the Tribal Historic Preservation Office of the Eastern Band of Cherokee Indians, and Illinois State University. 
speak a language in the Iroquoian linguistic group. Many Cherokees today live in western Oklahoma, a consequence of their forcible removal in the 19th century from their southeastern homeland in western North Carolina, eastern Tennessee, northern Georgia, northeastern South Carolina, and western Virginia. Eastern Cherokees are those who originate from this southeastern homeland, while Western Cherokees are those who hail from Oklahoma and adjacent regions. Acts of daily life to create, re-create, and sustain gadahu are referred to as \$SY (gadugi). Cherokee perspectives link the actions of people to their physical results, making a community a process with tangible outcomes. Anthropologists have written about gadugi work groups created for collective work details. ${ }^{2}$ When a person needs help, so teach the Elders, it is only proper to lend a hand, because intrinsic in the way the world should work is balance, $\Lambda \curvearrowright$ (tohi), created through mutual aid. So, gadugi is much more than one work crew and gadahu is more than a dot on a map - both constitute networks of social relationships whose origin is geographic. A community is not a thing, but a practice of social action that results in enduring connection to and stewardship of the social and physical landscape.

This perspective implies two consequences: first, the devastating effects of colonial policies of treating the landscape as a palimpsest from which Native American presence needed to be erased, and second, the opportunity for archaeology to aid in the effort to restore Cherokee connections to their heritage that have been severed or damaged by settler colonialism and its persistent legacies. Land is the site and embodiment of generations of legal travesties, memory, beauty in enduring practice, poetic semantic positioning, and brutal struggle. Colonial policies and processes, however, have done much to imbalance perceptions and experience of the land, an inequity for which the phrase landscape injustice is appropriate. One way to work towards restoring justice through equitable access to cultural landscapes and recognition of cultural heritage is to do what

2 FOGELSON, Raymond D. \& KUTSCHE, R.P. Cherokee Economic Cooperatives and the Gadugi. In: FENTON, W.N. \& GULICK, J.(eds.). Symposium on Cherokee and Iroquois Culture. Washington, D.C.: Smithsonian Institution, Bureau of American Ethnology Bulletin 180, 1961, p.83-123. 
seems impossible: reveal and recover that made invisible. Fortunately, archaeology can detect those tangible results and places created through the community action of gadahu. To illustrate these points, we offer an overview of a few examples of work conducted by the staff of the Eastern Band of Cherokee Indians Tribal Historic Preservation Office and Sampeck that show how a Cherokee presence in the landscape is being restored through archaeological research and education. By finding ways to hear a silenced past of Cherokee community building, we restore landscape justice and build a more equitable foundation for sustaining gadahu in the future.

\section{Understanding Cherokee communities}

Since 2009, the Tribal Historic Preservation Office (THPO) of the Eastern Band of Cherokee Indians (EBCI) and Sampeck have collaborated to build a program of archaeological research on the network of historic Cherokee towns. This research has a methodological and theoretical framework of landscape archaeology, which involves understanding the kinds of activities that took place in settlements; the urban spatial organization of domestic and public space; and the location and scope of agricultural fields and gardens, hunting grounds, and areas of gathering wild plants and other resources. This also involves understanding sacred places, as well as the roads and rivers that connected people and places. Excellent previous and ongoing work by other researchers work has focused on particular settlements ${ }^{3}$; our research orientation of gadahu highlights

3 DICKENS, Roy S. Cherokee Prehistory: The Pisgah Phase in the Appalachian Summit. Knoxville: University of Tennessee Press, 1976; DICKENS, Roy S. Preliminary Report on Archaeological Investigations at the Plum Grove Site (40W gl7), Washington County, Tennessee. Unpublished MS on file, Atlanta: Department of Anthropology, Georgia State University, 1980; GREENE, Lance K. The Archaeology and History of the Cherokee Out Towns. Volumes in Historical Archaeology, 40. Columbia: South Carolina Institute of Archaeology and Anthropology, the University of South Carolina, 1999; KEEL, Bennie C. Cherokee Archaeology: A Study of the Appalachian Summit. Knoxville: University of Tennessee Press, 1976; MARCOUX, Jon Bernard. Cherokee households and communities in the English Contact period, A.D. 1670-1740. Ph.D. 
how these areas beyond the immediate settlement are not just spaces between, but, in fact, the crucial context for community making. Our gadahu orientation shows that the landscape was not partitioned and segregated into urban versus rural settings, but instead people freely, necessarily circulated from river, field, mountain forest, and town to enact gadahu. Movement and action across the landscape created community rather than the settlement acting as an isolated unit apart from the countryside and/or forest. In the 16th through 18th centuries, trans-Atlantic colonists targeted these and other native cultural landscapes for undoing and destruction.

\section{Settler colonialism and Cherokee landscapes}

Colonial reordering of space, expressed as civilizing, moral order, was a way to exert power for achieving imperial schemes by physically preventing access for some people to crucial resources and by segregating people into controllable spaces. ${ }^{4}$ Sixteenth-century Spanish strategies in the Southeast were parasitic: Spanish colonists found major native settlements and built forts and towns alongside or in those native spaces in order to extract human and material resources as efficiently as possible. They gave Spanish names to the new constructions but continued to use native names as well. Later

dissertation. Chapel Hill: University of North Carolina, 2008. RIGGS, Brett. Removal Period Cherokee Households in Southwestern North Carolina: Material Perspectives on Ethnicity and Cultural Differentiation. Ph.D. dissertation. Knoxville: University of Tennessee, 1999. STEERE, Ben. The Archaeology of Houses and Households in the Native Southeast. Ph.D. dissertation. Athens: University of Georgia, 2011.

4 ETHRIDGE, Robbie. Creek Country: The Creek Indians and Their World, Chapel Hill: University of North Carolina Press, 2006; ETHRIDGE, Robbie. Introduction: Mapping the Mississippian Shatter Zone. In: R. ETHRIDGE \& S.M. SHUCK-HALL (eds). Mapping the Mississippian Shatter Zone: The Colonial Indian Slave Trade and Regional Instability in the American South. Lincoln: University of Nebraska Press, 2009, p. 1-62; ETHRIDGE, Robbie. From Chicaza to Chickasaw: The European Invasion and the Transformation of the Mississippian World, 1540-1715. Chapel Hill: University of North Carolina Press, 2010; SMITH, Marvin. Archaeology of Aboriginal Culture Change in the Interior Southeast: Depopulation during the Early Historic Period. Gainesville: University Press of Florida, 1987. 
British and American strategies involved systematic removal and resettlement, a re-landscaping to obscure or obliterate native presence.

The extreme violence of settler colonialism did not just contain indigenous residents in new ways through forced resettlement; even worse, it was an unseeing of their very presence. Though colonists judged and recorded resources - and saw people as one of the valuable resources - they did not connect native residents to the land. Instead, colonial policies were founded upon treating land as one thing and its residents as something separate, objectified, commodified, and thus removable. ${ }^{5}$

One of the earliest examples of landscape injustice from what eventually became the southeastern United States occurred in early January 1567. Pedro Menéndez de Áviles, the Governor of La Florida, ordered Juan Pardo to colonize and pacify the interior. Pardo founded the city (ciudad) of Cuenca and Fort San Juan, in the region of today's Morganton, North Carolina. ${ }^{6}$ Pardo explained that he chose this location, known by the Native American name Joara, for the Spanish town because of the large number of "Indians and caciques" (political leaders) who were resident or had come to the place (Figure 1). ${ }^{7}$ Despite vivid accounts of fertile agricultural fields and large towns filled with people, these Spaniards committed the first unseeing of southeastern Native Americans, erasing them from the landscape:

5 DENT, Joshua. False Frontiers: Archaeology and the Myth of the Canadian Wilderness. The University of Western Ontario Anthropology Journal, n. 21(1), 2013. p. 59-71.

6 BECK, Robin A., Jr., Christopher B. RODNING \& David G. MOORE (eds.). Fort San Juan and the Limits of Empire. Gainesville: University Press of Florida, 2016; BECK, Robin A. Chiefdoms, Collapse, and Coalescence in the Early American South. Cambridge: Cambridge University Press, 2013; BECK, Robin A., Jr., MOORE, David G., \& RODNING, Christopher B. Identifying Fort San Juan: A Sixteenth-Century Spanish Occupation at the Berry Site, North Carolina. Southeastern Archaeology, n. 25, 2006, p. 65-77; HUDSON, Charles. The Juan Pardo Expeditions: Explorations of the Carolinas and Tennessee, 1566-1568. Washington, D.C.: Smithsonian Institution Press, 1990; DEPRATTER, Chester, HUDSON, Charles \& SMITH, Marvin. Juan Pardo's Explorations in the Interior Southeast, 1566-1568. Florida Historical Quarterly, n. 62, 1982, p. 125-158.

7 BANDERA, Juan de la, II [1569] Proceedings for the Account Which Captain Juan Pardo Gave of the Entrance Which He Made into the Land of the Floridas. Translated by Paul HOFFMAN. In: Charles HUDSON (ed.). The Juan Pardo Expeditions: Explorations of the Carolinas and Tennessee, 1566-1568. Washington, D.C.: Smithsonian Institution Press, 1990, p. 205-296 [f5]; WORTH, John. The Struggle for the Georgia Coast. Tuscaloosa: University of Alabama Press, 2007. 
Pardo described that his goal was to work so that the "place called Joara should not remain a wilderness." ${ }^{8}$ Neither the people nor the communities, architecture, agriculture, and political regimes that so impressed and even nourished and safeguarded Spanish colonists counted as substantial endeavours. The ideology and processes of referring to and treating land as "wilderness," uninhabited, or widowed created a mandate for colonizing "empty" land that was in actuality the locale of Native American settlements or of subsistence, ritual, and other activities.

Figure 1

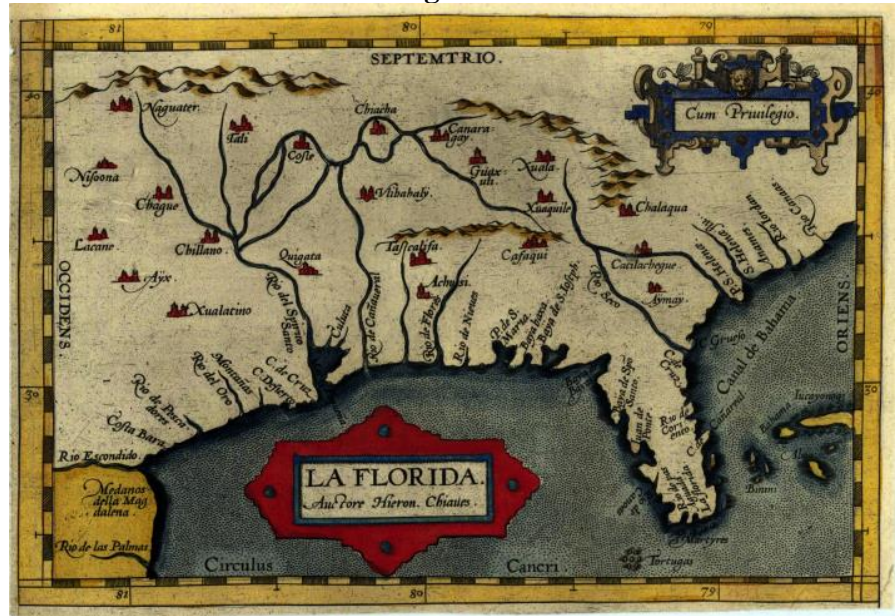

A Spanish view of Native American settlements and landscapes. The settlement of Joara is represented by "Xuala". La Florida (between 1582 and 1601), by Geronimo Chiaves and Abraham Ortelius (Digital ID: USFLDC:U15-0006). Special \& Digital Collections, Tampa Library, University of South Florida.Activité de simulation de fouilles archéologiques en 2014 (Nicolas Beaudry)

These places of native life and labour had names, of course, and some were more prominent - larger in size and/or population, or

8 BANDERA 1990[1569]:f5v. 
with residents who produced key resources or performed crucial activities. One of the most important places for Cherokees was, and still is, SSG (Kituwa). ${ }^{9}$ Archaeological survey and remote sensing have shown that Kituwa was not one of the largest settlements or an economic centre. Rather than being a centre of trade or political power, Kituwa was and is instead a reference point in Cherokee identity. Cherokees today refer to themselves as Ani-kituwagi, people of Kituwa ${ }^{10}$; everyone belongs to Kituwa, even if one lives or was born somewhere else. Kituwa was and is a crucial anchor for the network of Cherokee communities, referred to in colonial accounts as the Mother of all Cherokee Mother Towns. ${ }^{11}$ Despite this early recognition of Kituwa in historical records, Kituwa largely disappeared from documentary history by the 19th century. Colonial efforts to appropriate the landscape and people's connections to it involved killing the use of native names.

This erasure for unjust goals continues today. Many Cherokee community names, such as Kituwa, that appear in the 16thcentury conquest and colonization records of Hernando de Soto and Juan Pardo are still known today by members of the Cherokee community, but are overwritten by current, Anglo city names in official signs, and correspondence - and even in the way historians and educators refer to the places. The Native American part of history in these places is affixed to the remnants of town house mounds, while the rest of the settlement is obscured by contemporary development of "Franklin" or "Bryson City" or an unnamed agricultural field. The process of erasing Cherokee names from Cherokee places, making them seem vacant and therefore in need of development, continues today. This unseeing is a most brutal violence, as it unmakes one's very existence. There is nothing to survive if it is seen as never to have existed in the first place. Understanding past communities is one of the most relevant and effective ways to counteract centuries of concerted efforts to unmake

9 MOONEY, James. Myths of the Cherokee. Extract from the Nineteenth Annual Report of the Bureau of American Ethnology. Washington, D.C.: Government Printing Office, 1902.

10 MOONEY, 1902, p. 15.

11 MOONEY, 1902, p. 187. 
the Cherokee world and restores to a respectful place knowledge of the community that has been ignored or maligned.

\section{Goals and methods of community-centred archaeology}

The way investigators conduct research - the who and how is as important as the research questions they ask of past Cherokee landscapes - the why and when. One of the tenets of this work is "it's not about us without us," meaning that Cherokees not just consult, but plan and implement research, and then we share the results of that research in multiple modes to engage different segments of the community in beneficial ways. We have also worked for long-lasting, positive effects for participants in the work, such as providing professional training, educational experiences at different levels, and experience with innovative and cutting-edge methodologies. The goal is to achieve landscape justice in research, planning, and education.

\subsection{Advanced supervisory experience}

The field research has provided opportunities for professional development in graduate-level supervisory work. As field director, Beau Carroll, an enrolled member of the Eastern Band of Cherokee Indians and a THPO archaeologist, has trained graduate students from Illinois State University to supervise and train undergraduates from Illinois State University and other colleges in archaeological field and laboratory methods (Figure 2). Carroll organized and managed the field laboratory as well as the day-to-day implementation of the archaeological research plan. This is the kind of career-building experience that far too few Native archaeologists have had. 


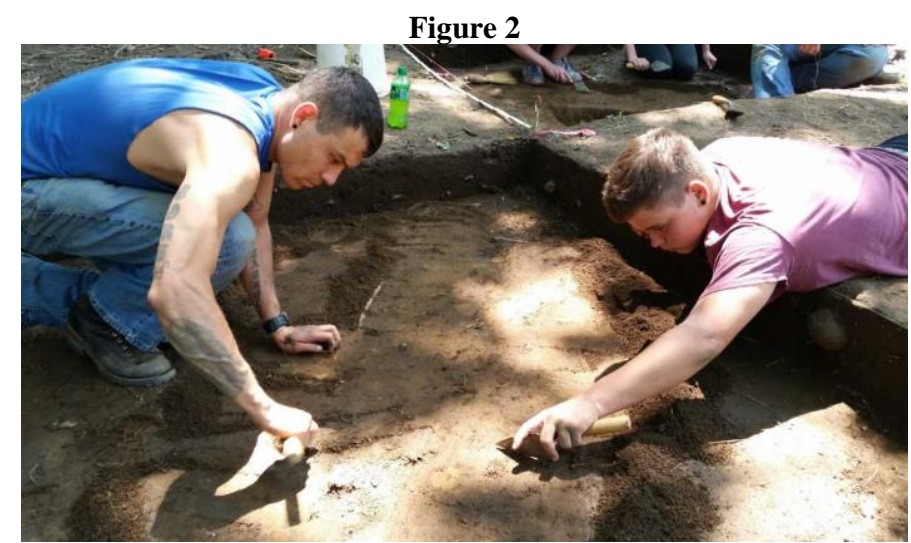

Beau Carroll and Damon Ayen excavating at Nvnvnyi in 2014. Photograph by Sampeck.

\subsection{Undergraduate and high school learning}

Every field season, we have had Native students, including enrolled Cherokee undergraduates and high school students. It is vitally important that community members are not just hearing about the work, but are doing it themselves. This on-the-ground experience is a building of awareness and appreciation of the community; the past is touched (artifacts, soil, topography) and felt (an emotional experience). It also changes the nature of the questions asked research questions come from Cherokee experiences today and from the knowledge they have learned through friends and family.

\subsection{Conversations with community leaders and residents}

At the end of every field season, students and staff present research findings to the Elders' Advisory Board. This event is a highlight for the students because they get a chance to get feedback from Elders as well as other stakeholders. The presentations have two parts, a formal presentation, followed by an interactive display (Figure 3). Students learn how to create and deliver a professional research presentation and respond effectively to questions. The interactive display involves selecting artifacts or other examples that 
give people a better chance to understand their research. Each student stands near his or her research poster (another valuable tool in communicating to professional and general audiences) and encourages attendees to ask questions and touch artifacts related to the presentation. The event fosters a community of common interests.

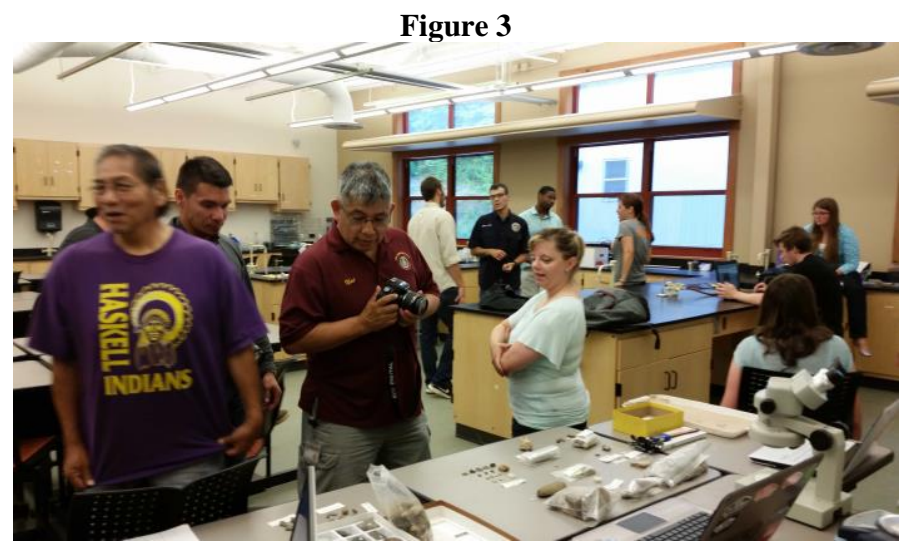

Interactive lab in 2015 at the Cherokee High School, Cherokee, North Carolina. Photograph by Sampeck.

\subsection{Communicating with scholars, professionals, and the public}

Disseminating results is the most important part of the research process, and to this end, we share findings in several different ways to reach different communities of academics, heritage preservation planners, and policy makers; the Cherokee community at home and abroad; and the general public. The archaeological work is steadily being published by peer-reviewed academic journals as well as shared in presentations at professional conferences, such as the Society for Historical Archaeology and the Southeastern Archaeological Conference annual meetings. To make the work as accessible as possible, students and staff also contribute to a website that presents a day-to-day perspective on archaeological discoveries. We are currently working on a mobile phone application that will link 
"hot spot" locations that will trigger a display of the Cherokee name of the place as well as historic photographs and compelling archaeological finds that illustrate the Cherokee heritage of that spot. In this way, appropriate information for different publics is available, with the goal of fostering a more equitable experience that restores a Cherokee presence to Cherokee places.

\section{Research Results and Landscape Justice}

This community-centred approach to investigating the Cherokee past has also made contributions to practices and understanding in the broader field of archaeology. Many of the innovations that helped us realize these insights came from the synergy with Cherokees in multiple, decisive roles and from the fresh perspectives that resulted from these roles. The research questions for investigation are better and the methodologies more appropriate, with results that speak for themselves. Three examples highlight ways in which archaeology can achieve landscape justice.

The first example recovered the actions of gadahu in the 16th century, interrogating specifically how to maintain connections between regions separated by imposing distances and topographical features. The consequence of approaching the work with Cherokee theoretical modelling of gadahu is a benefit for all archaeology in that it improves anthropological modelling of mobility.

The second example, dealing with the historic Cherokee town of Nvnvnyi, restores landscape justice by rendering visible a community's way of engaging with colonial pressures, showing that Cherokee communities participated in colonial networks on their own terms.

The final example of archaeological work, at the historic Cherokee town of Cowee, is a community-centered counterpoint to that of Nvnvnyi. The landscape justice in this case more fully comprehends the influential role of this place within the tumultuous dynamics of the Revolutionary War, not as a victim of British and 
revolutionary forces, but, rather, as an urban center and pivotal point in a network that addressed multiple Cherokee needs. Justice also occurs through recognizing how this place continues to hold a powerful role in the Cherokee cultural landscape today, including the common use of the toponym in signage as well as in common speech.

\section{Western Cherokee landscapes}

One important question to investigate was: When did European chronicles first describe Cherokee people or places? At the centre of this question is timing, which then lets us evaluate whether subsequent historical and archaeological narratives are fair or balanced. Were those descriptions of Cherokee places and people distinctive enough to match them to archaeological evidence? Several 16th-century accounts relate the travel of Hernando de Soto and his army in the Southeast in spring 1540 and the forays of Juan Pardo and his soldiers from the fort, San Juan, and town, Cuenca, that they established in $1567 .^{12}$ Both the documentary record and archaeological evidence indicate that these Spaniards had dealings in the Cherokee communities just west of the Appalachians. ${ }^{13}$

Our work in the Nolichucky Valley of today's Greene and Washington Counties in eastern Tennessee employed methodologies of landscape archaeology. We completed an intensive survey of artifact distributions and studies of "non-site" landscape features, such as roads, viewsheds, and access to resources, as well as

12 CLAYTON, Lawrence, KNIGHT, Jr., Vernon James \& MOORE, Edward C. (editors). The De Soto Chronicles: The Expedition of Hernando de Soto to North America in 15391543. 2 vols. Tuscaloosa: University of Alabama Press, 1993.

13 BECK, Robin A. From Joara to Chiaha: Spanish Exploration of the Appalachian Summit Area, 1540-1568. Southeastern Archaeology, n.16, 1997, p.162-169, 1997; HUDSON, Charles, SMITH, Marvin, \& DEPRATTER, Chester. The Hernando de Soto Expedition: From Apalachee to Chiaha. Southeastern Archaeology, n. 3, 1983, p. 65-77; SAMPECK, Kathryn, THAYN, Jonathan, \& EARNEST, Jr., Howard. H. Geographic Information System Modeling of De Soto's Route from Joara to Chiaha: Archaeology and Anthropology of Southeastern Road Networks in the Sixteenth Century. American Antiquity, n. 80 (1), 2015, p. 46-66. 
excavation of structures and features. This archaeological evidence shows that 16th- to 17th-century Cherokee settlement was aligned to access a wide travel route ample enough to accommodate armies as large as de Soto's, a main artery of exchange in the Southeast interior that continued in use from de Soto's to Pardo's time despite substantial shifts in the political landscape (Figure 4). ${ }^{14}$ Identifying the location of routes helps better characterize the nature of political shifts by identifying who was connected to whom and the nature of their linkages.

\section{Figure 4}

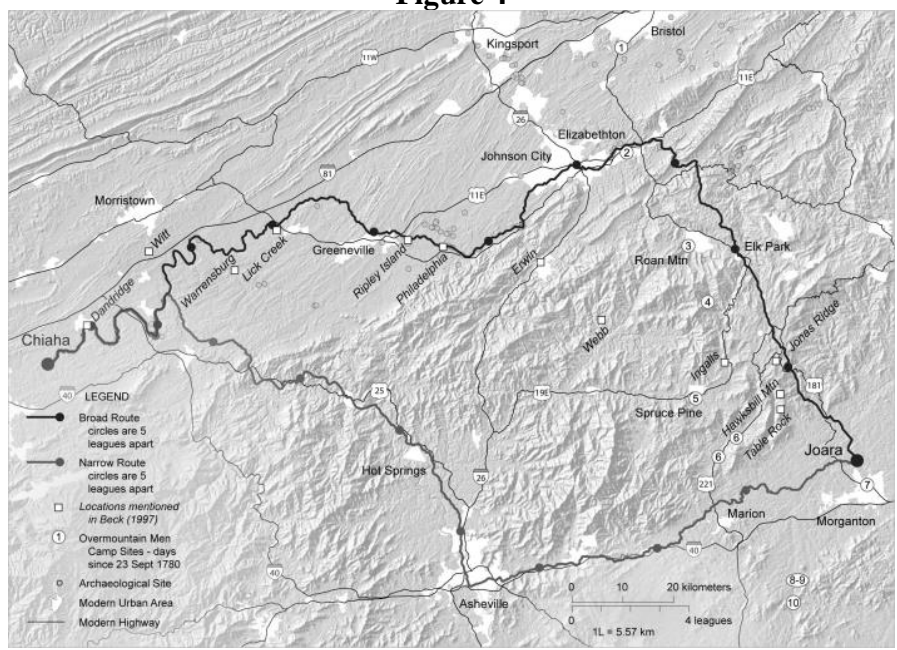

The likely route of Spanish expeditions through the western Cherokee region in the sixteenth century. Map by Jonathan Thayn.

This study made an important contribution to archaeological research in that this instance of modelling travel routes showed that all archaeologists and geographers must consider the number of members in the travelling party. The most favourable route varies dramatically depending on how many people are travelling together. 
In other words, movement of people is an anthropological problem, and like other sorts of social phenomena, the number of people participating affects logistics and dynamics of interaction. Our gadahu research orientation - asking how people formed communities and social networks through action and movement - was fundamental for contributing this anthropological insight.

That Cherokee settlements during the 16th and 17th centuries were all aligned along the road big enough for an army revealed a heretofore unappreciated aspect of social and political dynamics during the period. This is some of the first research focused on this time period in this part of the Cherokee world. The accommodations made for the movement of large groups seem to have fostered power for these Western Cherokee communities, suggesting that it was an emphasis on mobility and flexibility, rather than a large territory, that made Cherokee polities durable. Stability in Cherokee-ness came from strategic manoeuvring among and within community connections. Our research results presented exciting new ways to understand colonial developments and re-introduced this region as an innovative part of the Cherokee landscape. In other words, this research contributed to a more equitable view of the past and of Cherokee cultural landscapes.

\section{An Eastern Cherokee community: Nvnvnyi}

Our efforts to understand Cherokee cultural landscapes reaches also to the communities on the east side of the Appalachians. Although it is not indicated on contemporary maps, the settlement of Nvnvnyi lies near the downtown area of the contemporary city of Cherokee, North Carolina. The earliest written record of the settlement is the census of Cherokee towns by Varnod, in 1721, that records a population of 61 men, 56 women, and 60 children, a 
sizeable town at the time. ${ }^{15}$ Several other 18th-century maps also indicate the existence of the settlement. Historical documents, such as maps and trading accounts, suggest that Nvnvnyi was either abandoned or sparsely occupied after $1761,{ }^{16}$ but archaeological evidence indicates the continued presence of people there. Nvnvnyi is an excellent example of making visible a past that documentary evidence only partly records. This knowledge contributes to landscape justice by providing better information for planning, conservation, and education.

Archaeology has not always done a service to preserving heritage. Excavations at Nvnvnyi began in the 1880s, conducted by the Valentine family, who in many ways did all they could to dig up some of the most notable Cherokee public places and monuments. The destruction wrought by the Valentines was extreme because, in the absence of a THPO or State Historic Preservation Office, and of state or federal laws, there was no legislation in place to hold them in check. Edward Valentine excavated three trenches into the Nvnvnyi townhouse mound in 1882. Cherokees consider this a violation of sacred space that held the potential to extinguish the living core of the place. Further violation of Cherokee ethics was Valentine's excavation of 26 burials. Thankfully, the Valentines hardly excavated in the village portion, leaving much of the community space of Nvnvnyi relatively pristine.

Further disturbance and damage to the remains of Nvnvnyi occurred during the 20th-century construction of an amusement park. The "Cherokee Wonderland" amusement park began construction in the early 1960s, and the most damaging activities were the extensive landscaping and excavations to construct the water slide. The excavation of a drainage ditch just east of the mound triggered

15 VARNOD, Francis (1967 [1724]) "Letter to the secretary of [the] honorable Society for the Propagation of the Gospel in Foreign Parts to be left at the late Archbishop of Canterbury's library near St. Martin in the Fields," in Society for the Propagation of the Gospel in Foreign Parts (Great Britain) (ed.) Papers, 1635-1911. Microform. Ser. B, vol. 4, item 173. New York: Recordak.

16 GREENE, Lance K. The Archaeology and History of the Cherokee Out Towns. M.A. thesis, Department of Anthropology, University of Tennessee, Knoxville, TN, 1996; MCDOWELL, W.L., Jr. (ed.), Documents Relating to Indian Affairs May 21, 1750-August 7, 1754. Columbia, South Carolina: South Carolina Archives Department, 1958; SAUNDERS, William P. (ed.) Colonial Records of North Carolina, volume 10 (1775-1776). Raleigh, NC: State of North Carolina, 1890. 
archaeological mitigation in the form of recording of trench wall profiles. The construction of the Cherokee High School in 1975 further damaged remains of the historic settlement. The most problematic issue is that despite abundant remains, archaeological work on the one hand salvaged some information before its destruction, but on the other hand in some ways cleared a path for development of the area.

Subsequent archaeological work at Nvnvnyi included surface collection, test pit excavations, and gradiometer and ground penetrating radar surveys in the area of the village. All of this work was much less destructive than the disturbances of the Valentines. These projects were carried out in coordination with the Museum of the Cherokee Indian and funded by the National Park Service rather than EBCI official departments or programs.

Although remote sensing studies have the advantage that they do not disturb archaeological remains, they have the disadvantage that they do not tell us when the area was occupied - questions best addressed through careful excavations. The collaborative project between Illinois State University and the EBCI THPO placed three 2 by $2 \mathrm{~m}$ test units in areas indicated by remote sensing to have a high likelihood for structural remains. Preliminary results are clear: the units were almost devoid of nonlocal (that is, British or other European) goods. It is not likely that the people of Nvnvnyi had no access to trade goods, since British traders chose to locate there. It seems that Cherokees chose not to make those goods part of how they stored, prepared, or consumed food and drink.

This work has addressed several community landscape justice issues. It has shown how the current private landholders can best manage the cultural resources of the place. It has also shown the high quality of those resources, despite a disruptive past. And it has provided a much more nuanced view of Cherokee engagement with colonial commerce - an unwritten but powerful part of community history. 


\title{
Eastern Cherokee power of place: Cowee
}

\author{
Another vivid place in Cherokee and colonial US history was \\ the settlement of Cowee. Mooney ${ }^{17}$ recounted some highlights about \\ Cowee:
}

Cowee', properly Kawi'yi, abbreviated Kawi', was the name of two Cherokee settlements, one of which existed in 1755 on a branch of Keowee river, in upper South Carolina, while the other and more important was on Little Tennessee river, at the mouth of Cowee creek, about ten miles below the present Franklin, in North Carolina. It was destroyed by the Americans in 1876 [sic 1776], when it contained about a hundred houses, but was rebuilt and continued to be occupied until the cession of 1819 . The name can not be translated, but may possibly mean "the place of the Deer clan" (Ani'-Kawi'). It was one of the oldest and largest of the Cherokee towns, and when Wafford visited it as a boy he found the trail leading to it worn so deep in places that, although on horseback, he could touch the ground with his feet on each side.

There is a story, told by Waflford as a fact, of a Shawano who had been a prisoner there, but had escaped to his people in the north, and after the peace between the two tribes wandered back into the neighborhood on a hunting trip. While standing on a hill overlooking the valley he saw several Cherokee on an opposite hill, and called out to them, "Do you still own Cowee?" They shouted in reply, "Yes; we own it yet." Back came the answer from the Shawano, who wanted to encourage them not to sell any more of their lands, "Well, it's the best town of the Cherokee. It's a good country; hold on to it." 
Cherokees agreed with the advice of the Shawnee, but it took some time to recover ownership of Cowee after the disruptions of the 19th century. Our work concentrates on the site near Franklin, North Carolina. The current status of Cowee is nearly the opposite of that of Nvnvnyi. In 2006, The EBCI purchased a large parcel of land that has most of the dwellings, public constructions, related agricultural fields, and garden spaces of the settlement. The naturalist William Bartram, during his 1776 trip across the Southeast, said Cowee consisted of about 100 homes. ${ }^{18}$ Atop a mound, he wrote, was a council house "capable of accommodating several hundred people." While historical documents from as early as 1684 show that Cowee was a centre of commerce, with residents playing pivotal roles in political negotiations of the 17th and 18th centuries, these documents do not give us a detailed view of many important realms of Cherokee life.

Three kinds of archaeological information - imported glass beads, architectural remains, and fragments of metal - provide a view into what life was like at Cowee. Non-destructive analysis of artifacts and structural remains show how Cowee was part of a commercial network that spanned the Atlantic, that Cherokees worked iron, and that they conducted these activities in and around buildings and spaces that were uniquely Cherokee in their form and town plan. Our fieldwork has involved extensive survey using non-destructive techniques of Ground Penetrating Radar, magnetometry, and electrical resistivity to detect and assess patterns of anomalies. We have conducted two field seasons of strategically-placed test excavations to evaluate the features indicated by remote sensing. This approach maximizes the recovery of information with minimal impact to the long-term preservation of the site. In fact, the limited testing allows for much better evaluation of the remote sensing data, which inform future management plans.

Analysis of artifacts has called attention to activities that took place at Cowee, and to the relationships of Cherokee towns to goods

18 BARTRAM, William Travels Through North \& South Carolina, Georgia, East \& West Florida, the Cherokee Country, the Extensive Territories of the Muscogulges, or Creek Confederacy, and the Country of the Chactaws; Containing an Account of the Soil and Natural Productions of Those Regions, Together with Observations on the Manners of the Indians. Philadelphia: James \& Johnson, 1791. 
imported from Europe. X-ray fluorescence (XRF) is an efficient way to detect the chemical "recipe" of the different elements that compose glass. Different glass manufacturers used slightly different sources for their raw materials and the elements added to give different colours. The National Park Service provided both the equipment and the student training in how to use and interpret the results, an example of the benefits of multi-agency collaborative efforts.

Analysis of the chemistry of glass beads from Nvnvnyi and Cowee shows that some beads that looked slightly different from each other in fact had the same "recipe" of elements, while others that looked the same had different chemistry. The diversity of glass sources shows that a Cherokee at Cowee in the late 17th century in effect had the world on a string in a necklace or in embroidery on a belt, but that the diversity of sources was selected for consistency in appearance. Cherokees chose foreign goods that fit their aesthetic preferences and social needs; European goods served Cherokee ends.

XRF chemical analyses also show that objects recovered from test excavations in part of the urban settlement at Cowee appear to have a high iron content - likely slag from working iron, such as in a forge. This is one of the earliest occurrences of iron working in a Cherokee community. This possibility offers a view into competency in Cherokee life - they met skilled technological needs for crucial equipment right there in their own community.

These different activities took place in an environment arranged according to Cherokee design. The remote sensing imaging of buried features provides very good evidence of the form and spacing of buildings, revealing an urban plan that emphasized paired round and rectangular structures and large public plazas (Figure 5). The archaeological findings have yielded compelling details of ways in which Cherokees connected to each other and the colonial world. More detailed knowledge about Cowee contributes to landscape justice by highlighting the complexity and deep connections of this Cherokee community to both Cherokee and others' commercial, political, and social networks. The archaeological research at Cowee also enhances community education and heritage preservation activities, both of which are crucial in true landscape justice. 


\section{Figure 5}

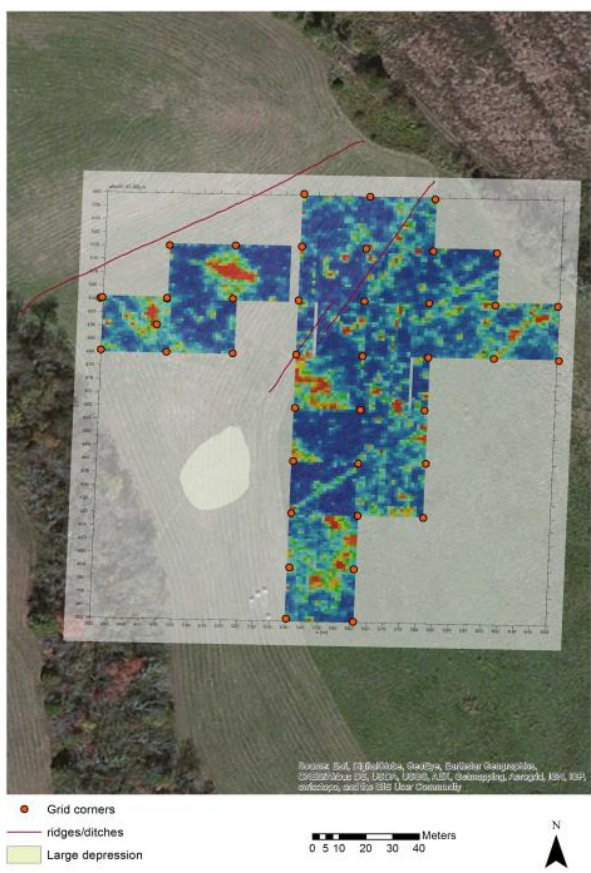

Grand Penetrating Radar imagery for a portion of the large plain at Cowee. Several likely structures are indicated by red and yellow zones. Image courtesy of Michael Seibert of the Southeastern Regional Office of the National Park Service.

\section{Discussion}

A pervasive pattern in the agenda of colonization was to erase Cherokee cultural memory by renaming places that were already established towns and dig up or build over physical remains. This disconnect continues with a remarkable silence about Cherokee 
contributions to American history in current education curricula. Cocreated and -managed archaeological research applying scientific methods can inform high-quality educational programs in a way respectful of, meaningful to, and directly benefiting the Cherokee people. The archaeological record is not an easy, straightforward read of a singular truth. Its advantage is that it can inspire dialogue and bring alternative evidence to dispute notions about the past and reclaim a heritage too often silenced.

Other papers in these two issues of História: Questões \& Debates rightly point out that archaeology can be a contested method for interpreting past communities and identities. Certainly, early phases of archaeological work at Nvnvnyi violated sacred contexts. By taking an approach that articulates the past, present, and future tenses of the living landscape, this project critically evaluates the ethics of cultural landscapes, particularly the crucial role played by archaeology in determining how people experience and understand the landscape and the implications of that knowledge for heritage conservation or transformation.

The research itself is an exercise of tohi, to restore some balance to the current dominance of the historical record, to broaden regions of research, and to balance Anglo history and understandings with Cherokee ones. The study of past relationships among people, other living things, and the material environment unveils how they inform life today and presents an opportunity for landscape justice. Landscape justice involves equitable access to the potential benefits of cultural landscapes and meaningful participation in plans, decisions, and actions regarding them, particularly the specific aspects of cultural heritage to sustain and transmit to future generations.

Deploying landscape ethics and justice has three crucial elements: (1) investigate the social, material, ecological and humanecological relationships, processes, and practices through which a landscape has been lived; (2) evaluate how investigations shed critical light on present-day relationships; and (3) connect the understanding of the past landscape with public discourse about its future and 
collaborate on planning for the landscape as it will and should be. ${ }^{19}$ While these three elements generally happen in stages, in our case they are all in play and have recursive effects on each other.

For example, the discoveries about routes connecting the Nolichucky Valley to areas east of the Appalachians brought to the fore the current cultural disconnect to that region, resulting in a stronger emphasis in educational materials to better demonstrate that this part of the Appalachians, too, has an indelible Cherokee past. Productive planning depends on understanding both the positive and the negative elements of landscape relationships and how they came to be. The differences in land ownership between Nvnvnyi and Cowee offer contrasting challenges and opportunities for community enhancement. The promise is that understanding the history of positive relationships will help sustain them in the future, while thorough evaluation of negative relationships can help determine how and why they might be dismantled or transformed. The social and political dimensions of interpretive tasks about heritage are significant; shared contribution, the partnership of archaeologists and community members, is one way to arrive at a tremendous mutual benefit. Together, we can co-create a powerful understanding of the past and the present that strengthens education and community development: we can work towards fulfilling the promise of gadahu.

RECEBIDO EM: 01/06/2018 APROVADO EM: 12/07/2018

19 DALGLISH, Chris. Archaeology and Landscape Ethics. World Archaeology, n. 44 (3), 2012, p. 327-341. 